Available online at GSC Online Press Directory

GSC Biological and Pharmaceutical Sciences

e-ISSN: 2581-3250, CODEN (USA): GBPSC2

Journal homepage: https://www.gsconlinepress.com/journals/gscbps

(RESEARCH ARTICLE)

\title{
Bioaccumulation of heavy metals in edible marine fish from coastal areas of Nellore, Andhra Pradesh, India
}

\author{
Vardi Venkateswarlu ${ }^{1,{ }^{*}}$ and Chenji Venkatrayulu ${ }^{2}$ \\ ${ }^{1}$ Research Scholar, Department of Marine Biology, Vikrama Simhapuri University, Nellore - 524 320, Andhra Pradesh, \\ India. \\ ${ }^{2}$ Assistant Professor, Department of Marine Biology, Vikrama Simhapuri University, Nellore - 524 320, Andhra Pradesh, \\ India.
}

Publication history: Received on 17 December 2019; revised on 10 January 2020; accepted on 11 January 2020

Article DOI: https://doi.org/10.30574/gscbps.2020.10.1.0244

\begin{abstract}
The worldwide increase in population, urbanization, and industrialization was affecting the natural aquatic environment in the form of pollution. The consumption of fishes as food has immense therapeutic and nutritional benefits. Heavy metal pollution of marine aquatic ecosystem occurring due to urban and industrial waste discharge, agricultural runoff and accidental spills of toxic chemicals is globally a rising concern and possesses a dangerous threat for human health due to their regular feeding habits. Humans consume fish as a dietary uptake without knowing the heavy metal accumulated from the polluted areas and are vulnerable to certain health risks. An attempt was made in the present investigation to monitor heavy metals concentration in coastal waters and edible marine fish Indian mackerel (Rastrelliger kanagurta) namely Arsenic (As), Lead (Pb), Cadmium (Cd), Mercury (Hg), Iron (Fe), Manganese $(\mathrm{Mn})$, Copper ( $\mathrm{Cu})$, Zinc (Zn) in water and fish tissues (Gills and Liver) of Nelaturu, Krishnapatnam coastal areas. The extent of metal concentrations in the water and levels of heavy metals varied among the various tissues in the fish species studied and the concentrations of the metals found in fish gill, liver tissues were high. At this rate, consumption of marine fish from Nelaturu, Krishnapatnam may lead to heavy toxicity and other related health problems to human and other animals. Control measures are required to reduce aquatic heavy metal pollution in the Nellore coast.
\end{abstract}

Keywords: Fish; Heavy metals; Nellore; Pollution; Toxicity

\section{Introduction}

Water quality of the coastal zones is deteriorating due to heavy metal pollution from sewage agricultural run-off. The most important issue arises when heavy metals that are released into the environment pose a threat to the aquatic life as well as their predators. The demand for fish consumption is gradually increasing to facilitate the growing population which in turn is increasing the pressure over the fish capturing sector. However, aquatic life is under constant threat due to pollution caused by various anthropogenic sources. Fishes are considered to be most significant biomonitors in aquatic systems for the estimation of metal pollution level [1,2] the global consumption of fishes has gradually increased in the last few years as fish consumption possesses great therapeutic and nutritional benefits. Being on robust demand for frozen shrimp and frozen fish in international markets, India had exported 11, 34,948 MT of seafood with a worth of over US $\$ 5.78$ billion (Rs. 37, 870.90 crores) in 2016-17. Southeast Asia remained the second largest destination of India's marine products, with a share of 29.91 percent in dollar terms, followed by Japan, the Middle East, China, and other countries. Visakhapatnam port from Andhra Pradesh, India exported 1, 59,973 tons of marine cargo worth Rs 9,294.31 crore (1,401.94 million US dollars) in 2016-17 as compared to 1, 28,718 tons worth Rs 7,161 crore (1,105.76 million dollars) in 2015-16.[3]. The concentration of heavy metals in aquatic organisms is higher than that present in

\footnotetext{
${ }^{*}$ Corresponding author

E-mail address: venkat9160@gmail.com
} 
water due to the effect of bio-concentration and bioaccumulation and eventually threaten the health of human by seafood consumption [4]. Rivers in India are highly polluted because of illegal discharge of industrial, agricultural and municipal waste. River damaged due to illegal sand mining in the riverside area also reduce the water flow which directly impacts on the ecology of aquatic organisms (CPCB 2011) [5].

The health status and the biological diversity of the Indian coastal ecosystems are deteriorating day by day through anthropogenic activities and, dumping of enormous quantities of sewage into the estuary has drastically reduced the population of the aquatic biota. It has also caused considerable ecological imbalance and resulted in the large-scale disappearance of their flora and fauna. Further, the introduction of untreated municipal waste-water and industrial effluents into these aquatic bodies has led to serious water pollution including heavy metal pollution, which gets biomagnified and reaches man through food chain implications. Heavy metals are a significant group of aquatic pollutants and have chief detrimental impact on human and environmental health [6,7] Discharge of heavy metals impacts on feeding behavior of fishes which makes vulnerable and heavily exposed to pollution because they cannot escape from the detrimental effects of pollutants [8] Degree of heavy metals in seawater and their distribution play an important role in influencing the productivity of marine ecosystem [9,10. Due to contamination of heavy metals in water and sediment with persistence for longer period cause serious threats to food chain, mostly fishes which can accumulate and biomagnifying the heavy metals [11,12]. Heavy metal pollution in aquatic ecosystem has been recognized as a serious environmental problem. In many cases, heavy metals occur in coastal water bodies at levels, even below their toxic thresholds, however, due to their non-degradable nature, such low concentrations may still pose the risk of damage via uptake and subsequent bioaccumulation by organisms. Under certain environmental conditions, heavy metals can accumulate to toxic concentrations and cause ecological damage [13]. So, heavy metals acquired through the food chain as a result of anthropogenic activities and pollution are potential chemical hazards that can threaten consumers. Metals such as zinc, copper, and manganese are essential metal since they play an important role in biological systems. Whereas lead and mercury are toxic even in a small amount. Aquatic organisms have the ability to accumulate heavy metals from various sources including sediments, soil erosion and runoff air deposition of pollutants and discharges of wastewater [14]. Therefore, accumulation of heavy metals in aquatic organisms can pose a longlasting effect on biogeochemical cycling in the ecosphere.

According to world health organization [15] metals occurs less than $1 \%$ of the earth's crust, with trace amount generally found in the environment and when these concentrations exceed a stipulated limit, they may toxic to the surrounding environment. The last three decades were witness to several reports on the toxicity of heavy metals in human beings, due to the contamination in the fish and fishery organisms $[16,17,18]$ The suggested Maximum Permissible Level (MPL) for heavy metals in the human diet as a safety regulation by international and national agencies such as the World Health Organization (WHO), the Joint FAO/WHO Expert Committee on Food Additives (JECFA), the Ministry of Agro-industry and Food Security (MAIFS) together with the Mauritian Food Act 1998 are set to identify the concentration of heavy metals in foods. Fulton's condition factor is used to calculate the relationship between the length and the weight of the fish in order to estimate the condition and feeding intensity of the fish [19]. Heavy metal pollution in rivers gives threat to public water supplies and also to the consumer of fishery sources [20]. Heavy metals constitute a core group of aquatic pollutants via its bio-accumulative and non-biodegradable properties in food [21] may be contaminated by organic and inorganic pollutants associated to aquatic systems by consumption of contaminated fish and other aquatic foods from this environment [22]. Studies on bioaccumulation of pollutants in fish are important in determining different content of trace metal in fish species from bio-magnifications of food chains, metabolic capability and feeding habits [23] the accumulation of metal is a tool for identifying the impact of metal in the aquatic ecosystem, and therefore shows an adverse effect in organism [24]. Aquatic water bodies contaminated by toxic heavy metals that may lead to accumulation in the food chain of an estuarine environment. Normally, such contaminants are transported from its sources through the river system and deposited downstream. Since most of the pollutants get mixed and become suspended as solid and bottom sediment through sedimentation, the estuary becomes a potential sink for these pollutants for a long period of time [25]. The wide diversity of human activities introduce pollutants into the environment, as well as their magnitudes which make the assessment of the environmental impact a subject of utmost interest [26]. Metal bioaccumulation by marine organisms has been the subject of considerable interest in recent years because of serious concern that high levels of metals may have detrimental effects on the marine organisms and may create problems in relation to their suitability as food for humans [27]. The objective of this study is to determine the concentration of some heavy metals in Indian mackerel fish Rastrelliger kanagurta, collected from Bay of Bengal from two different locations of Nelaturu and Krishnapatnam of Nellore coast, Andhra Pradesh.

\section{Materials and methods}

\subsection{Studyarea}


The Nellore district has a $169 \mathrm{~km}$ of the coastal line with habitation of fishermen community along the east coast of India. The Nellore coastal region is basically suitable for the brackish water aquaculture farming, recently gradually increased some industrial activities. The present sampling sites of Nelaturu and Krishnapatnam coastal areas are major fishing places in Nellore and nearby the sampling sites which consists of local markets in the village where the fishes caught from the sea coastal waters are regularly sold and near to the sampling sites have thermal power industries and also shipping activities from this coastal region. In the present study, a total of thirty fishes of Indian mackerel (Rastrelliger kanagurta) are collected with the support of local fishermen caught at the sampling site.

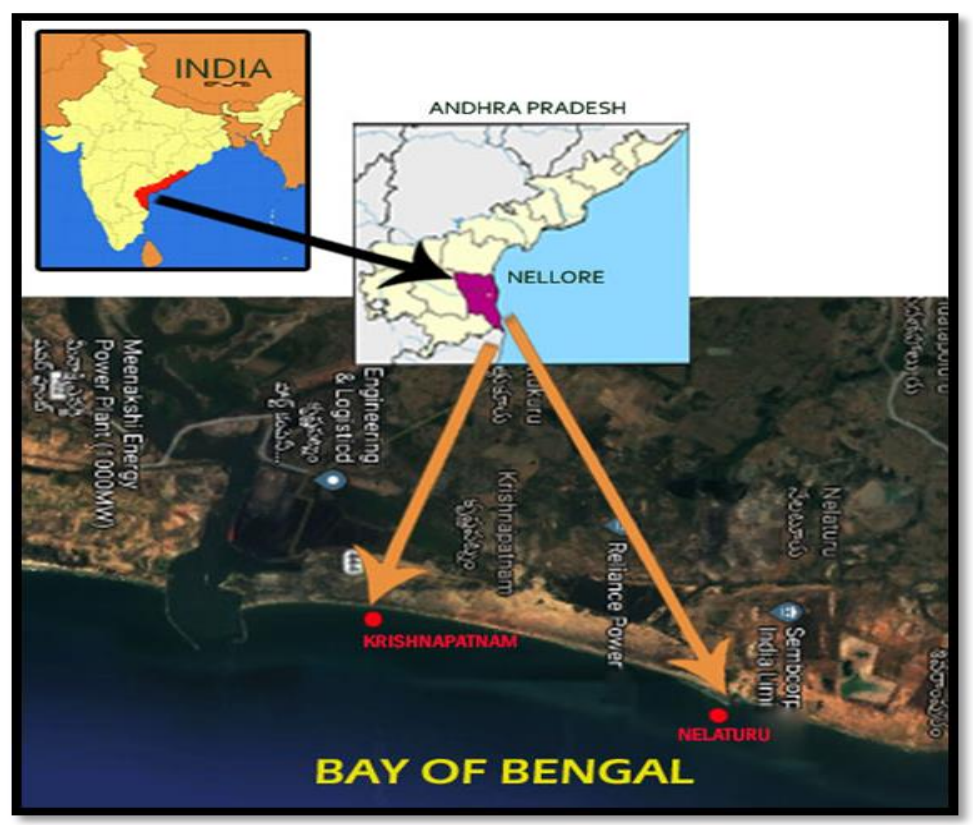

Figure 1 Map showing the study areas of Nelaturu and Krishnapatnam coastal regions of Nellore coast of Andhra Pradesh in India

\subsection{Sample collection}

Fish samples Indian mackerel (Rastrelliger kanagurta) from both sites were caught using gill nets from April 2019 and analysis were carried out according to APHA [28]. The nearest length and weight of each fish were measured. The fishes were washed using distilled water and place in separated polyethylene bags with ice. The samples were kept frozen at $4^{\circ} \mathrm{C}$ until ready for analyses.

\subsection{Sample preparation of fish}

All the glassware and plastics were soaked overnight in $10 \%(\mathrm{v} / \mathrm{v})$ nitric acid rinsed with distilled water and deionized water and dried before being used. Five gram of boneless muscle tissues Gills and Liver of Indian mackerel (Rastrelliger kanagurta) was collected separately using stainless steel knife and samples was digested in strong acid digestion (H2O2+HNO3 conc.) mixture at 1: 3 ratios [29] at $150^{\circ} \mathrm{C}$ for 20 minutes and allowed to cool at room temperature. Samples were processed in duplicate and then diluted to a total $50 \mathrm{ml}$ with ultra-pure water and filtered through 0.45 $\mu \mathrm{m}$ micropore membrane filter paper for analyses. All reagents were of analytical reagent grade. Ultra-pure water was used for all dilutions. The element standard solutions from Perkin Elmer that were used for the calibrations were prepared by diluting stock solutions of $\mathrm{mg} / \mathrm{ml}$.

\subsection{Heavy metal analysis}

All samples were digested in concentrated $\mathrm{HNO}_{3}$ and $\mathrm{H}_{2} \mathrm{O}_{2}$ in a beaker. The samples were diluted until $50 \mathrm{ml}$ with ultrapure water. After filtration, the prepared samples were determined for $\mathrm{As}, \mathrm{Pb}, \mathrm{Cd}, \mathrm{Hg}, \mathrm{Fe}, \mathrm{Mn}, \mathrm{Cu}$, and $\mathrm{Zn}$ by using atomic absorption spectrophotometer (AAS). Heavy metals included in this study are Arsenic (As), Lead (Pb), Cadmium (Cd), Mercury (Hg), Iron (Fe), Manganese (Mn), Copper (Cu), Zinc (Zn). Element standard solution from Perkin Elmer was prepared by diluting stock solutions of $100 \mathrm{mg} / \mathrm{ml}$ of each element based on (Abdulaliet al.,2003, Aderinolaet al., 2009) $[30,31]$. The concentrations of heavy metals were presented in $\mathrm{mg} / \mathrm{kg}$, wet weight $(\mathrm{WW}$ ) for the fish sample and $\mu \mathrm{g} / \mathrm{L}$ for water. 


\section{Results}

Heavy metal concentrations of Arsenic (As), Lead (Pb), Cadmium (Cd), Mercury (Hg), Iron (Fe), Manganese (Mn), Copper $(\mathrm{Cu})$, Zinc $(\mathrm{Zn})$ observed in commercially important edible marine fish Indian Mackerel (Rastrelliger kanagurta) represented in (Table 1)collected from the Nelaturu and Krishnapatnam coast of Nellore (Fig 1).

Table 1 Concentrations Mean \pm SD of Heavy metals $(\mu \mathrm{g} / \mathrm{g}$ ) present in fish (Rastrelliger kanagurta) from coastal regions of Nellore, Andhra Pradesh.

\begin{tabular}{|c|c|c|c|c|c|}
\hline \multirow{3}{*}{ S.No } & \multirow{3}{*}{ Name of the metal } & \multicolumn{2}{|r|}{ Nelaturu } & \multicolumn{2}{|c|}{ Krishnapatnam } \\
\hline & & \multicolumn{2}{|c|}{$\begin{array}{l}\text { Indian Mackerel } \\
\text { (Rastrelliger kanagurta) }\end{array}$} & \multicolumn{2}{|c|}{$\begin{array}{l}\text { Indian Mackerel } \\
\text { (Rastrelliger kanagurta) }\end{array}$} \\
\hline & & Gills & Liver & Gills & Liver \\
\hline 1 & Arsenic (As) & ND & $0.050 \pm 0.016$ & ND & ND \\
\hline 2 & Lead $(\mathrm{Pb})$ & $0.112 \pm 0.23$ & $0.352 \pm 0.031$ & $0.19 \pm 0.012$ & $0.055 \pm 0.014$ \\
\hline 3 & Cadmium (Cd) & ND & $0.05 \pm 0.007$ & ND & $0.629 \pm 0.17$ \\
\hline 4 & Mercury (Hg) & ND & $0.05 \pm 0.005$ & ND & ND \\
\hline 5 & Iron $(\mathrm{Fe})$ & $71.42 \pm 10.29$ & $53.02 \pm 7.16$ & $460.76 \pm 62.34$ & $96.52 \pm 16.81$ \\
\hline 6 & Manganese (Mn) & $5.36 \pm 1.08$ & ND & $8.06 \pm 0.91$ & ND \\
\hline 7 & Copper $(\mathrm{Cu})$ & $1.59 \pm 0.65$ & $24.13 \pm 5.37$ & $1.35 \pm 0.075$ & $29.14 \pm 3.64$ \\
\hline 8 & Zinc $(\mathrm{Zn})$ & $42.16 \pm 10.51$ & $28.42 \pm 7.59$ & $20.64 \pm 2.64$ & $39.03 \pm 4.92$ \\
\hline
\end{tabular}

\section{Discussion}

Aquatic pollution is one of the major rising problems globally and it also affects the total seafood demand from India. Fish is an important dietary source of protein but due to the increasing level of heavy metals in water, fishes tend to bioaccumulation and concentrate the smallest amount of heavy metal present in water. And in turn, this poses a greater risk to human beings due to our dependency on fish as a part of our diet. Ingesting of polluted marine fish and exposure to heavy metals causes health problems in people and animals which includes neurological and reproductive problems [32]. Heavy metals are one of the more toxic pollutants in our natural environment due to their toxicity. The efficiency of metal uptake from polluted water may different ecological need, metabolism, and contaminated level, food, and sediment as well as other environmental factors such as temperature, salinity, and interacting agent. When the organisms are exposed to high-level metal in an aquatic environment, they can absorb the available metals directly from the environment via the gills or contaminated water and food, thus accumulated them in their tissues and enter the food chain and extend to so many other problems to humans [33].Table 1 shows that heavy metals observed in fish (Rastrelliger kanagurta) collected at Nelaturu coast, concentrations of metals Lead (Pb) 0.112 \pm 0.23 , Iron (Fe) 71.42 \pm 10.29 , Manganese (Mn) 71.42 \pm 10.29 , Copper (Cu) 1.59 \pm 0.65 , Zinc (Zn) 42.16 \pm 10.51 are more than permissible levels and Arsenic (As), Cadmium (Cd), Mercury (Hg) were not observed in the gills of the fish and in Liver Arsenic (As) $0.050 \pm 0.016$, Lead $(\mathrm{Pb}) 0.352 \pm 0.031$, Cadmium (Cd) $0.05 \pm 0.007$, Mercury $(\mathrm{Hg}) 0.05 \pm 0.005$, are more than permissible levels, Iron (Fe) 53.02 \pm 7.16 ,Copper (Cu) 24.13 \pm 5.37 , Zinc (Zn) 28.42 \pm 7.59 were observed high concentrations and Manganese (Mn) were not observed in the liver of the fish, collected from the Nelaturu coast. Heavy metals observed in fish (Rastrelliger kanagurta) collected at Krishnapatnam coast, concentrations of metals concentrations in the gills Lead (pb) $0.19 \pm 0.012$, Copper $(\mathrm{Cu}) 1.35 \pm 0.075$, are more than permissible levels, Iron (Fe) 460.76 $\pm 62.34, \mathrm{Zinc}(\mathrm{Zn})$ 20.64 \pm 2.64 , Manganese (Mn) 8.06 \pm 0.91 observed more in the gills and Arsenic (As), Cadmium (Cd), Mercury (Hg) were not observed in the gills of the fish and heavy metals concentrations observed in the fish Liver Lead (pb) $0.055 \pm 0.014$, Cadmium (Cd) 0.629 \pm 0.17 are more than permissible levels and Arsenic (As), Mercury (Hg), Manganese (Mn) were not observed in the liver of the fish in Krishnapatnam area observed high levels of Iron (Fe) 96.52 \pm 16.81 , Copper (Cu)29.14 \pm 3.64 , Zinc $(\mathrm{Zn}) 39.03 \pm 4.92$ in the liver of the fish.

Based on the results, the present study revealed that fishes can be used as bio-indicators for marine pollution [34].Hence in order to take early precautions related to human health concerns, studying of marine pollution and heavy metal 
accumulation is very important. The fish species selected for the study was due to their higher consumption rate and consumer preference in the study area. The heavy metals were selected due to their availability in the study area.

\section{Conclusion}

The Present study was carried out in order to focus on the accumulation of certain heavy metal levels in the water and fish. In conclusion, the results of the present study indicated a moderate presence of heavy metals in the coastal water and accumulation in the gills, liver, and muscles of Indian mackerel fish (Rastrelliger kanagurta) showed a tendency to accumulate higher levels, due to runoffs containing sewage, Industrial and toxic pollutants. Some fisherman still using the same area for fishing. At this rate, consumption of fish from Nelaturu and Krishnapatnam coast of Nellore may lead to biomagnification of heavy metal toxicity of man and other animals. Hence, it is evident that due to subsequent industrialization, the entry of toxic effluents is increasing the risk of metal contamination in the environment which contributes to its further entry into human beings through food chains. Control measures are required to reduce lead pollution in the present study area.

\section{Compliance with ethical standards}

\section{Acknowledgments}

Authors were thankful to the local fishermen of the sample stations who are helped for sample collection, and also thankful to the Vimta Labs for providing the sample analysis facilities.

\section{Disclosure of conflict of interest}

Authors declared that there no conflict of interest.

\section{References}

[1] MN Rashed. (2001). Monitoring of environmental heavy metals in fish from Nasser Lake, Environ. Int. 27-33.

[2] MMN Authman. (2008). Oreochromisniloticus as a biomonitor of heavy metal pollution with emphasis on potential risk and relation to some biological aspects, Global Veterinary. 3 104-109.

[3] India's Seafood Export at all-time High in MPEDA. (2016). Press Information Bureau, Government of India, Ministry of Commerce \& Industry.

[4] SEIshaq, SA Rufus and PA Annune. (2011). Bioaccumulation of Heavy Metals in Fish (Tilapia Zilli and Clarias Gariepinus) Organs from River Benue, North n Central Nigeria Pak. J. Anal. Environ. Chem. 2, 25-31.

[5] CPCB. (2011). Impact of Coal Mine Waste water Discharge on surroundings with reference to heavy metals. Central Pollution Control Board Bhopal.

[6] BStreit. (1992). Bioaccumulation processes in ecosystem experiential 48: Birkhauser Verlag CH 4010. Basel Switzerland. 955.

[7] Y Saavedra, A Gonzalez, P Fernandez and J Blanco. (2004). The Science of the Total Environment, 318, 115-124.

[8] MMN Authman, MSZ aki, EA Khallaf EA and Abbas HH. (2015). Use of Fish as Bio-indicator of the Effects of Heavy Metals Pollution. Journal of Aquatic Research Development, 6 (4), 1-13.

[9] Baahner and FMM Morel. (1995). Phyto chelatin Production in marine algae: Induction by various metals. Limnol. Oceanogr, 40, 658-665.

[10] MI Wells, GI Smith and KW Bruland, (2000). The distribution of colloidal and particulate bioactive metals in Narragansett bay. Mar. Chem, 71, $143-163$.

[11] G.Bhuyan and R. Anandhan. (2013). Bioaccumulation of Metals ( $\mathrm{Zn}, \mathrm{Ni}, \mathrm{Cr}, \mathrm{Cd}$ and $\mathrm{Pb}$ ) in Tissue of Freshwater Teleost Oreochromismossambicus(Tilapia) From Kedilam River, India. Pollution. Res, 32, 797-801.

[12] G Bhuyan, R Anandhan and V Kavitha. (2014). Qualitative and Quantitative Analysis of Fish Tissue of Oreochromismossambicus Collected from Kedilam River, Cuddalore, Tamil Nadu, India. Int. J. Applied Sci. Biotech, $2,135-141$. 
[13] KO Guven, Cunlu and E Satar A. (1999). Acute, lethal Toxicity and an Accumulation of Copper in Gammaruspulex (L.) (Amphipoda).Turk J Biol. 23, 513-21.

[14] TH Goodwin, AR Young, MGR Holmes, GH Old, N Hewitt andGJL Leeks. (2003). The temporal and spatial variability of sediment transport and yields within the Bradford Beck catchment, West Yorkshire. Sci. Total Environ, 314, 475-494.

[15] WHO. (1999). Inorganic Mercury-Environmental Health Criteria. Geneva World Health Organization. 118-1591.

[16] BP Batvari, S Kamala-Kannan, K Shanthi, R Krishna moorthy, KJ Lee and M Jayaprakash. (2008). Heavy metals in two fish species Carangoidel malabaricus and Belone stronglurus from Pulicat lake, north of Chennai, southeast coast of India. Environ. Monitoring and Assessment,145, 167-175.

[17] EA Mohamad and AR Osman. (2014). Heavy metals concentration in water, muscle and gills of Oreochromisniloticus collected from the sewage treated water and the White Nile. Inter. J. Aquacult, 36-42.

[18] PV Krishna, V Jyothirmayi and K Madhusudhana Rao. (2014). Human health risk assessment of heavy metal accumulation through fish consumption, from Machilipatnam coast, Andhra Pradesh, India. Int. Res. J Public Environ. Health, 5, 121-125.

[19] K Alghwela, AB Ahmed and AB Abol-Munafi, (2011). Condition factor as an indicator of growth and feeding intensity of Nile Tilapia fingerlings (Oreochromisniloticus) feed on different levels of maltose. Am-Euras J Agric. Environ Sci, 11, 559-63.

[20] BF Terra, FG A raujo, CF Calza, RT Lopes and TP Teixeira. (2008). Heavy metal in tissue of three fish species from different trophic levels in a tropical Brazilian river. Water Air Soil Pollut,187, 275-284.

[21] U Kazim, K Esengul, B Metin, D Muhammet, E Yunus, K Mustafa, O Cigdem and OOzmal. (2008). The comparison of heavy metal accumulation ratios of some fish species in Enne Dame Lake (Kutahya/Turkey). Environ. Monit.Assess, 157, 355-362.

[22] OJ Aderinola, EO Clarke, OM Olarinmoye, V Kusemiju and MA Amatekhai. (2009). Heavy metals in surface water, sediments, fish and Perwinkles of lagos lagoon. American-Eurasian J. Agric. \& Environ. Sci, 609-617.

[23] FE Asuquo, I Ewa-Oboho, EF Asuquo and PJ Udo. (2004). Fish species used as biomarker for heavy metal and hydrocarbon contamination for Cross River, Nigeria. Environmentalist, 24, 29-37.

[24] U Borgmann and WP Norwood.(1995). Kinetics of excess (above background) copper and zinc in Hyalellaazteca and their relationship to chronic toxicity. Can. J. Fish. Aquat. Sci, 52, 864-874.

[25] DJMorrisey, SJ Turner, GN Mills, RB Williamson and Wise BE. (2003). Factor affecting the distribution of benthic macro fauna in estuaries contaminated by urban runoff. Marine Environ. Res, 55, 113-136.

[26] JE Marcovecchio. (2004). The use of Micropogoniasfurnieri and Mugilliza as bioindicators of heavy metals pollution in La Plata river estuary, Argentina. Science of the Total Environment, 323, 219-226.

[27] HHHAhdy, AMA Abdullah and FT Tayel. (2007). Assessment of heavy metals and nonessential content of some edible and soft tissues. Egyptian. J. Aqua. Res, 33, 85-97.

[28] APHA AWWA, WEF, Standard Methods for The Examination of Water and Waste Water21st ed. American Public Health Association, Washington, D.C, 2005.

[29] M Durali, FU Omer, T Mustafa andS Mustafa. (2010). Determination of trace metals in different fish species and sediments from the River Yesilirmak in Tokat, Turkey. Food. Chem. Toxicol. 48, 1383-1392.

[30] T Abdulali, M Shuhaimi-Othman and AK Ahmad. (2003). Assessment of heavy metals in tilapia fish (Oreochromisniloticus) from the Langat river and engineering lake in Bangi, Malaysia and evaluation of the health risk from tilapia consumption. Ecotoxil. Environ. Saf. 93. 45-51.

[31] OJ Aderinola, EO Clarke, OM Olarinmoye, V Kusemiju and MA Amatekhai. (2009). Heavy metals in surface water, sediments, fish and Perwinkles of lagos lagoon. American-Eurasian J. Agric. \& Environ. Sci. 609-617.

[32] K Sobha, A Poornima, P Harini and K Veeraiah. (2016). A study on Biochemical Changes in the Fresh water Fish, Catlacatla (Hamilton) Exposed to the Heavy Metal Toxicant Cadmium Chloride, Kathmandu. Int. J. Res. Fish. Aqua,4, 84-93.

[33] AK Ahmad andSHMOthman. (2010). Heavy metal concentrations in sediments and fishes from Lake Chini, Pahang. Malay. J Biol. Sci, 10, 93-100. 
[34] E Padmini and M Kavitha. (2005). Contaminant induced stress impact on biochemical changes in brain of estuarine grey mullets". Poll. Res, 24, 647-651.

\section{How to cite this article}

Vardi V and ChenjiV (2020). Bioaccumulation of heavy metals in edible marine fish from coastal areas of Nellore, Andhra Pradesh, India. GSC Biological and Pharmaceutical Sciences, 10(1), 18-24. 